\title{
クエン酸錯体法による $\mathrm{Mn}_{5} \mathrm{O}_{8}$ の合成と酸素還元電極触媒への応用
}

\author{
营原 陸郎 ${ }^{*}$, 大野 正道, 遠藤 孝志, 松木 健三
}

\section{Preparation of $\mathrm{Mn}_{5} \mathrm{O}_{8}$ by Citrate Process and Its Application to Electrocatalyst for Oxygen Reduction in Alkaline Solution}

\author{
Michio SugAwARA*, Masamichi OHNo, Takashi Endo and Kenzo Matsuki
}

Received December 27, 1992 ; Accepted May 23, 1992

\begin{abstract}
A manganese oxide, $\mathrm{Mn}_{5} \mathrm{O}_{8}$, was prepared by a citrate process and applied to the electrocatalyst for oxygen reduction in alkaline solution. The oxygen electrocatalysis of $\mathrm{Mn}_{5} \mathrm{O}_{8}$ supported on graphite was studied by a rotating ring-disk electrode method. This manganese oxide showed the catalytic activity for 4-electron reduction of oxygen on graphite.
\end{abstract}

\begin{abstract}
1 はじめに
酸化物触媒の調製法とししてクエン睃錯体法1,2)が注目 され、多くの研究が行なわれている、この方法では，比 表面積が大きく，また混合酸化物を合成するときには， 組成の均筫なものが得られるので，鳋媒活性が向上する

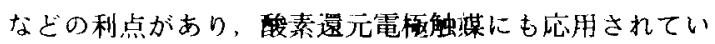
る. 3,4
\end{abstract}

酸素谴元電極触媒には，種々の酸化物が伈用されてい るが，三浦らは，ペロブスカイト型酸化物に注目し，一 連の與味ある結果を報告している，らこのとき，触媒 をクエン酸錯体法で調整すると，酸嗉僈元能が向上する ことを明らかにしている．著者らも，マンガンを含む二， 三の酸化物を酸素還元電極触媒に応用した結果を報告し

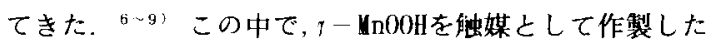
ガス搪散電極は，触媒活性が高いこ上を認めている。 この原因として，ガス搪散電極を作㡀する過程で熱好理

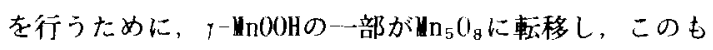
のが酸素還元に対して触媒活性が高いためであると考え ている.

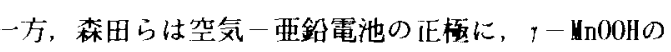

山形太学工学部物質工学科 (广992米沢市城南4-3-16) Department of Materials Science and Engineering Yamagata University, Yonezawa, Yamagata 992, Japan Key words: $\mathbf{n}_{5} \mathbf{0}_{8}$, Citrate process, 0xygen electro catalysis
熱分解によって $\mathrm{Mn}_{5} 0_{8}$ に富む酷化物を調製して，酸素還元 の触媒に応用し，補聴器用ボタン型奄池を開発した。10) このように, $\mathrm{n}_{5} 0_{8}$ は酸素遗元に対して触媒活性が期待さ れるが、詳紐な検討は行な゙われていない。

著者らは，クエン酸錯体法で硝酸マンガンからマンガ ン酸化物を合成する反応に具昧をもち，検討を進めてい る、この中で, 硝酸マンガンとクエン酸から得られるク エン酸塩前駆体を酸素気流中で熱分解すると，単一相の $\mathrm{N}_{5} 0_{8}$ が生成することを報告した。 ${ }^{11}$ 本報では，空気一 金属電池の正溗へ応用するこしを目的とし，このように して得られた $n_{5} 0_{8}$ を触媒に用いるアルカリ水溶液中で の酸素還元反応について検討した。

\section{1 試料の調製}

$$
2 \text { 実験 }
$$

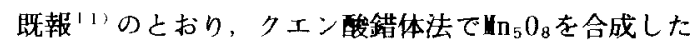
すなわち、ロータリーエバポレターを用い，約 $60{ }^{\circ} \mathrm{C} て ゙$ 硝 酸マンガンとクエン酸の等モル水溶液を粘椆な液体にな

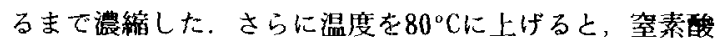
化物が発生し，粉末状のマンガンのクエン酸塭前駆体が 得られた。これを出発物質として酸素気流中, $400^{\circ} \mathrm{C} て ゙$ 熱 分解して $\mathrm{Hn}_{5} \mathrm{O}_{8}$ を得た。比較のため，7-MnOOHを文献'2) の方法にしたがって合成し，ついで窒素霝囲気中で熱分 解して $\mathrm{H}_{5} 0_{8}$ に富む酸化物を調製した。

得られた酸化物は，硫酸鉄（II）法 ${ }^{33}$ およびビスマス 酸ナトリウム法"4にによ，それぞれ有效酸素と全マンガ 
ンを分析し、Mn0xとしたときの $\mathrm{x}$ 值を求めた。また，粉 末 $\mathrm{X}$ 線回折の測定（理学電機, RAD-1A)，此表面積の測定 (島津製作所一マイクロメリテックス，2200)およびSEM 観察(日立製作所，S-550) などを用いてキャラクタリゼ ーションを行なった.

\section{2 酸素還元反応}

酸素還元は，RRDE法により検討した.リング電極には 金 $(\mathrm{Au})$ を用いた。ディスク電極は, 既報 ${ }^{6)}$ のよおりに 調製したペースト電極である。触媒 $\left(\mathrm{N}_{5} \mathrm{O}_{8}\right)$ とグラファ イト(Lonza，KS-44)を重量比で20：80に混合し, 少量の パラフィンでペースト状にして金ディスク上に充填した． RRDEの形状から求めた捕捉率は（N）は0.388であった. 電解液には，酸素を飽和させた1 moldm. ${ }^{3} \mathrm{NaOH}$ 用い， 酸素這元反応の分棈曲線を测定した。リング電極では， $\mathrm{H}_{2} \mathrm{O}_{2}$ の酸化反店を検出するため，電位を 300 四 V Vs. $\mathrm{Hg} /$ HgOに設定した。なお，測定は室温で行なった。

\section{3 結果および考察}

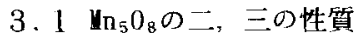

Table 1に，二つの方法で得られた $\mathrm{Mn}_{5} \mathrm{O}_{8}$ 二二，三の性 質をまとめて示した，xの値をみると，クエン酸錯体法 で得られたものは，量論比 (1.600)に近い值であり，前 報11)で示したとおり，単一相の $\mathrm{Mn}_{5} 0_{8}$ が生成しているも のと考えられる.しかし，ー一助00Hの熱分解で調製した

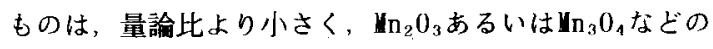
酸化物が含まれていることが予想される。これらの值は， 熱分析から（1 )式の反応に基づいて計算した值とよく一 致した。

$$
2 \mathrm{Nn}_{5} \mathrm{O}_{8} \longrightarrow 5 \mathrm{Hn}_{2} \mathrm{O}_{3}+1 / 20_{2}
$$

Table l Some characteristics of $\mathbf{Y n}_{5} \mathbf{O}_{8}$

\begin{tabular}{|c|c|c|c|}
\hline $\begin{array}{l}\text { Preparation } \\
\text { method of } \\
\ln _{5} 0_{8}\end{array}$ & $\begin{array}{l}\text { Specific } \\
\text { surface } \\
\text { area }\left(\mathbf{⿴ 囗 十}^{2} \mathrm{~g}^{-1}\right)\end{array}$ & $\begin{array}{l}x \text { Value } \\
\text { in } \mathbf{Y n 0 x}\end{array}$ & $\begin{array}{l}\text { Conductivity } \\
\left(\mathrm{S} \mathrm{cm}^{-1} \times 10^{6}\right)\end{array}$ \\
\hline $\begin{array}{l}\text { Citrate } \\
\text { process }\end{array}$ & 16.0 & 1.61 & 3.5 \\
\hline $\begin{array}{l}\text { Decomposition } \\
\text { of } 1-100 \mathrm{H}\end{array}$ & 3.1 & 1.54 & 3.9 \\
\hline
\end{tabular}

クエン酸錯体法で得られる酸化物の特徽の一つは, 比 表面積が大きいことである．本実験で得られた $\mathrm{Mn}_{5} 0_{8}$ は， 7ーMnOOHを出発物質としたものに較べると, 約 5 倍の比 表面積を与えた。

酸化物粉末をプレスしながら，窒温で電子導電率を测 定したが，両者には大きな違いが楒められなかった。こ
の值は，同じ結晶構造をとる $\mathrm{Ca}_{2} \mathrm{Mn}_{3} \mathrm{O}_{3}$ と同程度であり， 絶縁体に近いものであった。15

Fig.1に，クエン酸錯体法およびマーMnOOHから得られた $\mathrm{Nn}_{5} \mathrm{O}_{8}$ のSEU写真在示した。比較のため, 出発物質である

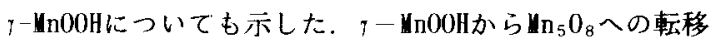

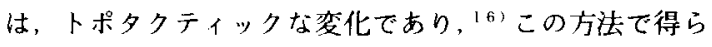
れるものは，出発物鹠の粒子形状を保持している．しか し，クエン酸錯体法からのものは，約1 «以以の一次粒 子が凝集した多れ体であることが示㕹され，この方法の 特徽を表わしていると考えられる。

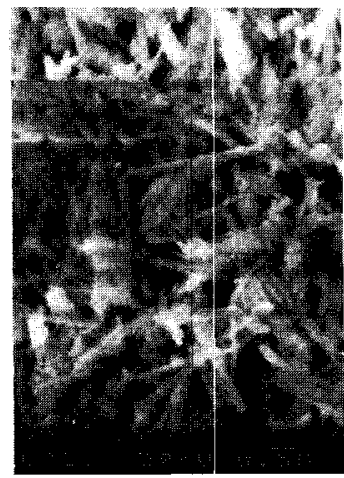

$y-\mathrm{MnOOH}$

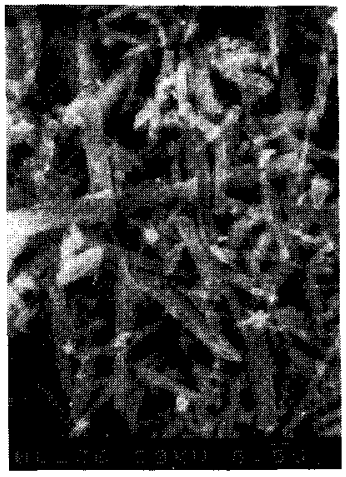

$\mathrm{nn}_{5} \mathrm{O}_{8}$ from $7-\mathrm{MnOOH}$

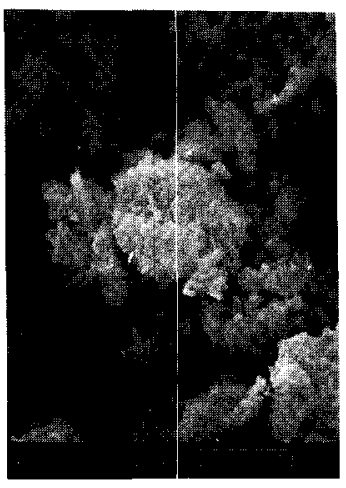

$\ln _{5} 0_{8}$ by citrate process

Fig. 1 SEM micrographs of $7-\mathrm{n} 00 \mathrm{H}$ and $\mathrm{In}_{5} 0_{8}$ prepared by different methods

\section{2 酸素還元反店と電極触媒}

Fig. 2 に，RRDE法により測定した分極曲線を示した. 図から明らかなように，触媒として $\mathrm{n}_{5} \mathrm{O}_{8}$ を添加すると， ディスク電流は增加し，リング電流は减少している。こ の効果は,クエン酸錯体法から得られた $\mathrm{Nn}_{5} 0_{8}$ のほうが大 きく，触媒活性の向上が誌められた：また，掃引方向に より分極曲線には，七ステリシスが見られるが、これは 表面状態の変化に起因しているものと考えられる。

一般に認められているように，アルカリ水溶液中にお 
ける酸素の還元は,グラファイト上では睃素の 2 電子還 元による過酸化水素 $\left(\mathrm{HO}_{2}{ }^{-}\right)$の生成反応が進行し， $\mathrm{HO}_{2}{ }^{-}$ の分解は起こらない，本奏験においても，クラファイト 単独の場合, リング電流はデスク電流に捕捉率を乗じた 值に対庒しているので，この反応が主に起こっているこ 亡が確かめられた．したがって， $\mathbf{n}_{5} 0_{8}$ を添加した電桠 でみられるリング電流の城少は，酸素の直接 4 電子還元 あるいはHO

また，触媒を添加した電槙は，グラファイト単独のもの に比べて約100mV貴な電位から電流が流れており，この ときのリング電流が流れ始める電位は，グラファイト単 独の場合と変わりはなかった。

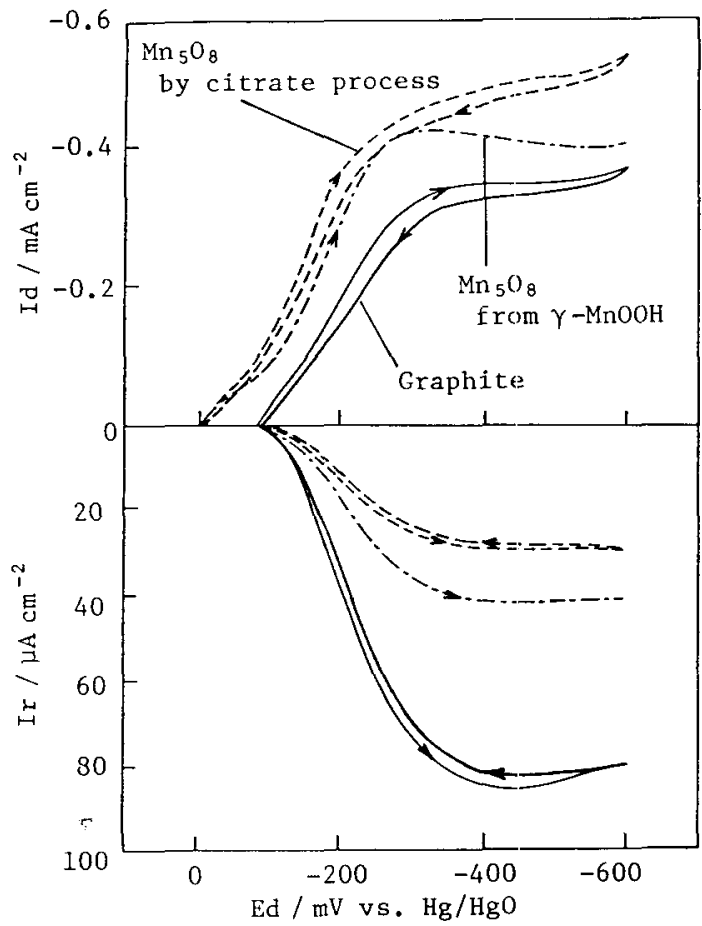

Fig. 2 Disk potential(Ed)-disk current(Id) and ring current( $\mathrm{Ir}$ ) curves in $\mathrm{O}_{2}$-saturated $1 \mathrm{M} \mathrm{NaOH}$ at rotation rate of $1000 \mathrm{rpm}$ Sweep rate $: 5 \mathrm{mV} \mathrm{s}^{-1}$

$\mathrm{Mn}_{5} \mathrm{O}_{8} /$ Graphite $: \mathrm{I} / 4$ by weight

アルカリ水溶液中での酸素から水 $\left(0 \mathrm{H}^{-}\right)$への還元反応 は，中間体の $\mathrm{HO}_{2}{ }^{-}$を考虑して次のように表わされている

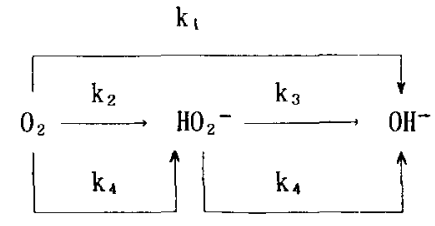

それぞれの段階の速度定数 $\left(\mathrm{k}_{1} \sim \mathrm{k}_{4}\right)$ を見積もるには， RRDE法が有効であり，この方法で酸素嗃元電極触媒が評 牦されている。 ${ }^{6,17)}$ 本実験においても，この方法に基 ブいて酸素嗃元電極の触媒活性を比較した.

酸素還元が溶存酸素に対して一次であれば，(2)式が 成立し，1ノ钟を并に対してプロットした勾配から，

(3)式にしたがって，反応電子数 $(n)$ を求めることがで きる、また，( $\left.\mathrm{I}_{\mathrm{d}} / \mathrm{I}_{\mathrm{r}}\right) \mathrm{N} と \omega^{-1 / 2}$ のプロットから（4）お よび( 5 )式を用い， $\mathrm{k}_{1} / \mathrm{k}_{2}$ および $\mathrm{k}_{3}+\mathrm{k}_{4}$ を見積もる ことができる。

$$
\begin{aligned}
& 1 / I_{d}=1 / I_{k}+(1 / B) \omega^{-1 / 2} \\
& \mathrm{~B}=0.62 \mathrm{nFC}_{n 2} \mathrm{D}^{1 / 3} y^{-1 / 6} \mathrm{~s}(2 \mathrm{x} / 60)^{1 / 2} \\
& \text { ここで, } I_{d}: \text { ディスク電流, } I_{k} \text { : 反応電流 } \\
& \omega \text { : 電樰回転数, } \mathrm{C}_{\mathrm{O}_{2}} \text { : 酸素濃度, } \mathrm{D} \text { : 搪散係数 } \\
& \text { y：動粘度， } \mathrm{S} \text { ：電極表面揹 } \\
& \mathrm{N}\left(\mathrm{I}_{t} / \mathrm{I}_{\mathrm{r}}\right)=1+2 \mathrm{k}_{1} / \mathrm{k}_{2}+\mathrm{A}+\mathrm{A} \mathbf{\omega}^{-1 / 2} \\
& A=a\left\{\left(2 k_{1} / k_{2}\right)\left(k_{3}+k_{1}\right)+\left(2 k_{3}+k_{4}\right)\right\} \\
& \text { ここで, } \mathrm{N}: \text { 捕捉率, } a, \mathbf{1}: \text { : 定数 }
\end{aligned}
$$

$\mathrm{Nn}_{5} 0_{8}$ の電子導電率は小さいので, ディスク電流はグラ ファイトおよびグラファイトと $\mathbf{n}_{5} 0_{8}$ の界面で起こる電 気化学反応に上るもので，単一プロセスからなるものと は考えられない，しかし，ディスク電極上で起こる酸素

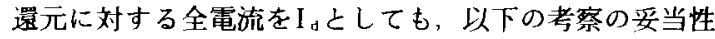
は失われないものと考えられる。

Fig. 3およびFig. 4は,クエン酸錯体法で調製した $\mathbf{M n}_{\mathbf{5}} \mathrm{O}_{8}$ を触媒に用いて測定した分極曲線から，それぞれI ${ }^{-1} お$ よびN( I 。/ I a $)$ とい あるＦig.3に示したとおり，電位心よらず平行な直線が 得られ，この電極上での酸素還元は，溶存酸素に对して

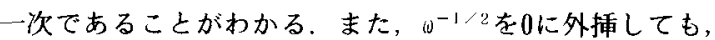
直線は原点を通らないので，ディクの限界電流は単純

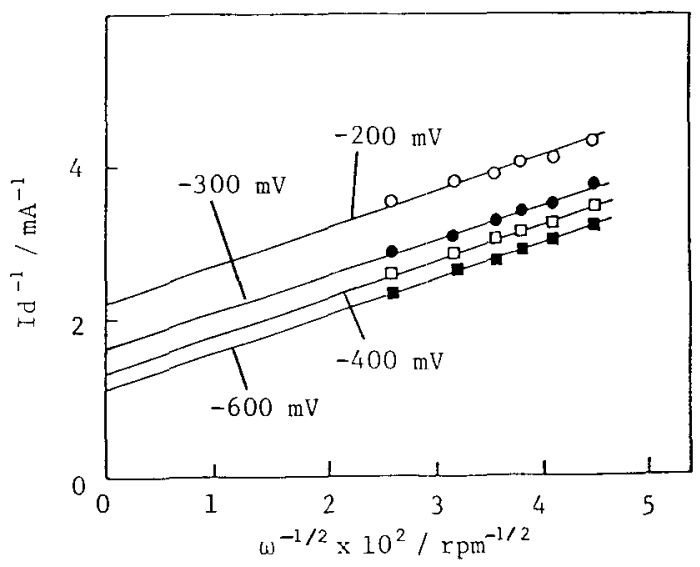

Fig. 3 Id $^{-1}$ vs. $\omega^{-1 / 2}$ plots at various disk potentials from Ed-Id curves 


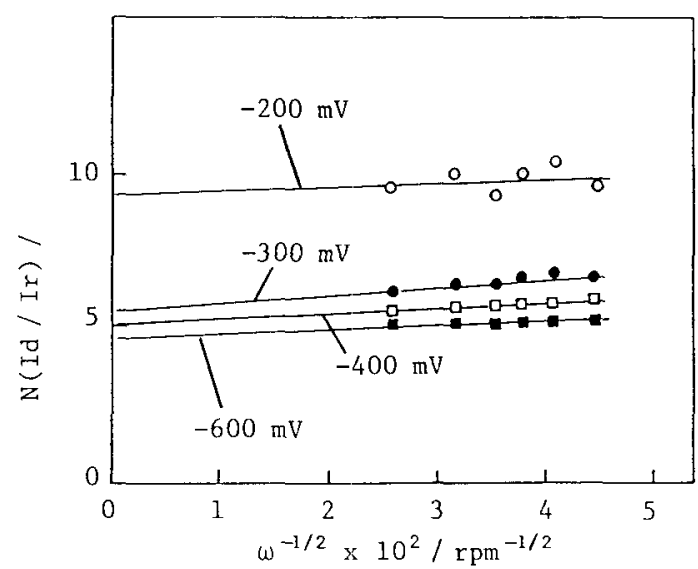

Fig.4 N(Id/Ir) vs. $\omega^{-1 / 2}$ plots at various potentials from Ed-Id and Ir curves

な搪散支誈ではないことは明らかである。直線の勾能か ら B 值を求め，(3)式により， nの值を見積もることが できる.さらに，Fig. 3のプロットは，勾配が0に近い值 であり, $\mathrm{k}_{3}+\mathrm{k}_{4}$ の值を 0 と近似すると, 切片から $\mathrm{k}_{1} / \mathrm{k}_{2}$ の值を求めることができる。このような傾向は, $7-$ MnOOH

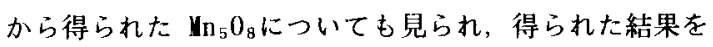
Table 2にまとめて示した。

Table 2 Some electrochemical properties

\begin{tabular}{lccc}
\hline & & \multicolumn{2}{c}{$\mathrm{k}_{1} / \mathrm{k}_{2}$} \\
\hline $\begin{array}{l}\text { Cirate } \\
\text { process }\end{array}$ & 4.0 & 4.2 & 2.2 \\
$\begin{array}{l}\text { Decomposition } \\
\text { of } r-\mathbf{Y n O H}_{8}\end{array}$ & 2.9 & 2.0 & 0.7 \\
\hline
\end{tabular}

クエン酸錯体法で得られる $\mathrm{N}_{5} 0_{8}$ では, $\mathrm{n}$ の值は 4 であ り，酸素の 4 電子還元が起こっていることが示晙される. また， $\mathrm{k}_{1} / \mathrm{k}_{2}$ の值も大きく，4電子還元が優先して起こっ ていることが分かる。このような強媒活性の向上は，比 表面積が大きく，単一層に近い酸化物を用いたことによ るものと考えられる.クエン酸錯体法による $\mathrm{Mn}_{5} 0_{8}$ の合

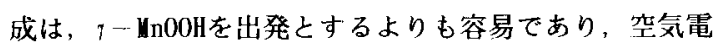

池などの酸素逜元電樯の触媒へ応用することが期待され る.

文 献

1) D. J. Anderson, F. R. Sale, Powder Metal1., 22, 14 (1979).

2) M. S. G. Baythoun, F. R. Sale, J. Mater. Sci., 17, 2757(1982).

3) Y.Shimizu, K. Vemura, N. Yamazoe, Chem. Lett., 1988, 1979.

4）清水洋一，三浦則雄，山添 昇，日化，1988， 1501.

5）清水洋一, 上村賢一, 三浦則雄, 山添 昇, 日化 1990，1323. 清水らのグループの酸素這元電極触媒 に関する研究の一連の文献がまとめられている。

6）松木健三, 森 重哉, 鎌田 仁, 電気化学, 51, 691 (1983).

7）松木健三，森 重哉，鎌田 仁，電気化学，52，129 (1984).

8) K. Matsuk i, H. Kamada, Electrochim. Acta, 31, 13 (1986).

9）松木健三，鎌田 仁，日化，1986，109.

10）森田是宣, 小西 始, National Technical Report, $32,590(1986)$

11) M. Sugawara, M. Ohno, K. Matsuki, Chem. Lett., $1991,1465$.

12) 日本化学全螎, “新奏験化学講座 8 ”, 丸善, p. 284 (1976).

13) D. Glover, B. Schumm Jr., A. Kozawa, "Handbook of Manganese Dioxide”, IBAInc., p. 21(1989).

14）高木誠司, “定量分析の奏験之計算 2 ”, 共立出版, p. 379 ( 1969).

15）菅原陸郎, 遠藤孝志, 松木健三，電気化学，57， 539 (1989).

16) J.H. Rask, P. R. Buseck, Am. Mineral, 71, 805 (1986).

17) I. R. Trasevih, A. Sadkowski, E. Yeager, "Comprehensive Treatise of Electrochemistry" 7, edtd. by B.E. Conway et a1., Prenum Press, N. Y. , p. 301(1983). 